\title{
Relationship of screening results development with KPSP method and results of measurement of growth parameters in children in Denpasar-Bali
}

\author{
D A A A S Astini ${ }^{1 *}$ and Ni Komang Trisna Sumadewi ${ }^{1}$ \\ ${ }^{1}$ Department of Anatomy, Medical Faculty and Health Science of Warmadewa University, Bali- \\ Indonesia \\ *sukesukaastini@yahoo.com
}

\begin{abstract}
Measurement of growth and development is the most important thing in children, and it relates to early treatment when found abnormalities in growth and development. Growth measurements performed on weight, height and head circumference. Some previous research found many delays on child development. There are several ways that can be used to perform screening on the development, one of them by using the questionnaire, i.e. pre-screening questionnaire development (KPSP) that require special officers are trained in their implementation. The results of the measurement of growth is often associated with the development of the child. Based on the foregoing, required further research regarding the relationship between screening on the development and growth in children. The purpose of this research is to analyzed the relationship between the results of the screening on the development by using KPSP and the results of measurement of parameters of growth in children ages 0-6 years in Denpasar. Research carried out using cross sectional analytic. Based on the correlation of Pearson test $(\alpha=0.05)$, indicating there is a significant negative correlation $(r=-0.218 ; \mathrm{p}$ $<0.05)$ between body weight and development. This suggests that the higher the weight will further lower the level of child development.
\end{abstract}

Keyword : Development, KPSP method, Children.

\section{Introduction}

The first 6 years of age is the golden period of growth and development of the child. The measurement of growth and development in children are routinely done every month. It is to know early lapses on growth and development. Head circumference, weight, and height is three parameters on growth as measured in children to know the accuracy of children's growth. Whereas the development of the child can be assessed by using the pre-screening questionnaire development (KPSP).

Various studies have been conducted to assess the many developments in children, such as research conducted in America that shows one in five children are having problems in development. Other research conducted in Netherland shows $14 \%$ of children experience problems of development. Developmental delay is also found in children in Taiwan, there was an increase of $7.7 \%$ from the year 2003 to 2007 [1]. Other studies conducted in the city of Malang in Indonesia showed a $2.1 \%$ toddlers have a developmental delay [2]. Research on the city of Cianjur in Indonesia showed a $25.6 \%$ of children have developmental aberrations and $20.9 \%$ of the children have the possibility of aberration progression of (dubious) [3]. Research 
conducted at the Daycare Werdhi Kumara in Denpasar showed that $13.9 \%$ allegedly has a developmental delay [4].

KPSP is a developmental screening instruments that are adopted from prescreening developmental questionnaire (PDQ). These instruments have been recommended by the Ministry of Health in Indonesia to be carried out at the place of Primary Health Care [5]. But in practice, KPSP may only be carried out by trained personnel [6].

In addition to the developmental screening instruments KPSP, there are other developmental screening instruments have been widely used by the world health professions, including Indonesia, that the Denver II [5]. This instrument can be used for screening of development ranging from newborn up to age 6 years, and include a wider developmental aspects compared to KPSP [7]. However, the use of instruments of the Denver II is more complicated, long, and should be done by trained personnel, as well as the trend of the results is influenced by the level of education of parents of the child [7], [8]. Based on the research of Dhamayanti (2006), KPSP sensitivity when compared to the Denver II, have a low value $(60 \%)$ of the value that should $(>70-80 \%)$, therefore the KPSP may cause underdetection on child development because about $40 \%$ of children suspected developmental delay may become undetectable [8].

Measurement of the head circumference is a reliability index to estimate the volume of the brain and can reflect on the cognitive ability and general development in children early. The curve of the head circumference that is outside of the standard deviation is usually followed by a problem of development in children[9]. Based on previous research indicates that there is a significant relationship between height, weight and head circumference with the development in children [10], [11].

This research aims to know the development and growth in children in Denpasar. In addition, the study also aims to find out the results of the screening method with KPSP developments, measurement results on the growth parameters, and knowing the relationship between developmental screening results by using the methods and results of KPSP measurement of growth in children ages 0-6 years in Denpasar. Monitoring on growth and development of children is a very crucial thing to do in order to know of any deviations on both. This monitoring also aims to improve the health and nutritional status, cognitive, mental and psychosocial. This monitoring is carried out by health workers who work in primary healthcare services, paramedics, social officer, professional organizations and related stakeholders [12], [13].

Monitoring on growth is periodic measurements in children age 0 to 72 months with weight measurements every month, height measurements every 3 months, and head circumference measurements in as scheduled. Monitoring the developments done every 3 months in children age 0 to 12 months, and every 6 months in children ages 12 to 72 months. These monitoring activities should be done in a comprehensive, including adequate stimulation, detection and early intervention in disorders of growth and development in children [12], [13].

The development is an ongoing process and is associated with the maturation of the central nervous system. Assessment of the development of the child is usually done using KPSP. Aspects that are assessed in the form of the development of motor skills, fine motor, language and psychosocial.

This questionnaire contains a short list of questions addressed to the parents to be able to do early detection of deviations in the development in children age 0 to 72 months. Examination schedule KPSP routinely was at the age of 3, 6, 9, 12, 15, 18, 21, 24, 27, 30, 33, 
$36,39,42,45,48,51,54,57,60,63,66,69$ and 72 months. If the child is not present the age appropriate, then it can come back on the age of the nearest screening [13].

\section{Method}

The research design used is cross sectional analytic. The research was carried out at the unified service post and primary school in Denpasar. Samples of research used in this research is as much as 96 children ages $0-6$ years.

Data that has been collected tested correlation using the Pearson test to find out the correlation between the results of developmental screening with KPSP methods and measurement results of growth parameters

Growth measurements were carried out directly by researchers using a digital weight scale brand of "Camry" with accuracy of $0.1 \mathrm{~kg}$ and measuring instruments for brand height "Microtoise GEA" with accuracy of $0.1 \mathrm{~cm}$.

Measuring height:

1. Microtoise hanging on the wall that is straight and flat, and as tall as 2 meters. The number 0 (zero) on a flat floor

2. Shoes or sandals are released

3. The subject stands upright; foot straightened out; heels, buttocks, back, and the back of the head should be attached to the wall; and the face is facing straight ahead

4. Microtoise lever later reduced until it docked at the top of the head, the angle of the lever must be straight stick on the wall

5. The numbers on the scale, which looks at the hole in the roll of microtoice shows the height of the subject.

Measuring height:

1. The initial scale on the weight scale are on point 0 (zero)

2. Shoes or sandals are released

3. The subject standing erect

4. The numbers on the scale shown on the scales indicate weight of the subject.

Developmental screening is done using the Pre-Development Screening Questionnaire (KPSP). The aspects assessed were gross motoric development, fine motoric, language and psychosocial. This questionnaire contains a short list of questions addressed to parents on children aged 0 to 72 months. Examination schedule KPSP routinely was at the age of 3, 6, 9, $12,15,18,21,24,27,30,33,36,39,42,45,48,51,54,57,60,63,66,69$ and 72 month.

\section{Results And Discussion}

Samples researched as much as 96 children, consisting of 55 men $(57.3 \%)$ and 41 females $(42.7 \%)$. The entire sample has been measured weight, height, head circumference and developments, as well as data analysis has been carried out. 
The data is distributed normally, Pearson correlation test is performed between weight and development; height and development; and head circumference and developments.

Based on the correlation of Pearson test $(\alpha=0.05)$, indicating that there is a meaningful negative correlation $(r=-0.218 ; \mathrm{p}<0.05)$ between body weight and development. This suggests that the higher the weight will further lower the level of child development. Based on the correlation of Pearson test $(\alpha=0.05)$, indicating that there was no correlation $(r=-0.151 ; p>$ $0.05)$ between height and development and there was no correlation $(\mathrm{r}=-0.135 ; \mathrm{p}>0.05)$ between head circumference and development (Table 1).

Table 1. The result of a Pearson correlation test between weight, height, head circumference with child development.

\begin{tabular}{lcc}
\hline \multicolumn{1}{c}{ Variable } & Correlation coefficient (r) & Nilai p \\
\hline Weight & -0.218 & $0.033^{*}$ \\
Height & $-0,151$ & 0,143 \\
Head circumference & -0.135 & 0.189 \\
\hline * Correlation is significant at the 0.05 level (2-tailed) &
\end{tabular}

In this study it was found that there was a significant negative correlation between body weight and child development. This suggests that the higher the weight will further lower the level of child development. This research is in line with research conducted on children in Iran, suggesting that in children who are obese and overweight tend to experience slower motor development than other children who have normal body weight or thinner [14]. Development is influenced by several factors such as hereditary factors, the environment, early stimulation and attention of parents, and child nutrition. In this study body weight can be associated with nutritional intake in children. Excessive nutrient intake can cause children to lack activities and influence children's development[15],[16],[17].

The growth and maturation of children is influenced by the constant interaction between genes, hormones, nutrients and other factors. This factor may also affect physical performance. Other factors that come from the environment such as the season, dietary restrictions, severe psychological stress, only affect the rate of growth. Other factors such as socio-economic class can also affect the period of child growth and development[18].

One of the most important components to support the sustainability of the development of the child is the intake of nutrition. Assessment of nutritional status can be done directly with the measurement of anthropometry, such as weight, height and head circumference. Measurement of weight and height is an important procedure done to get information about children's health. Children grow and develop quickly, so this growth and development should be evaluated at regular intervals[9]. Based on the research of Alfarizi and Suarni (2015), it was found that there is a significant relationship between nutritional status and development in children ages 3-4 years in the city of Palembang in Indonesia. Nutritional status was obtained based on the height and weight of the child[11], [16].

Previous research also suggests that other factors such as early cognitive stimulation in children through preschool education have a positive effect on psychomotor skills. Lack of optimal cognitive stimulation due to poor home environment and absence of preschool education leads to a delay in child development. Other factors also play a role in children's development, including the education status of both parents, especially fathers, have an effect on achieving child development. Maternal education has a positive relationship with the ability of a child in the face of a physical environment, exposure to various stimuli, including 
the proper selection of games or toys, and the maternal emotional and verbal involvement of the child [19].

\section{Conclusions}

Based on growth parameters, only weight related to child development. This is likely related to nutritional status in children. Further research is needed regarding other factors that influence and relate to child development.

\section{References}

[1] Ayele M. 2014. Developmental Delays among Infants and Young Children in Addis Ababa: Screening, Risk Factors and Intervention. Doctoral Dissertation. Addis Ababa University

[2] Ariani, Yososaputro M. 2012. Usia Anak dan Pendidikan Ibu sebagai Faktor Risiko Gangguan Perkembangan Anak. Jurnal Kedokteran Brawijaya. 27(2), 118-121

[3] Susanti N. 2014. Deteksi dini masalah perkembangan anak taman kanak-kanak dengan menggunakan KPSP (Kuesioner Pra Skrining Prekembangan). Universitas Pensisikan Indonesia

[4] Hartawan INB., Windiani IGAT., Soetjiningsih. 2008. Karakteristik Tumbuh Kembang Anak di Tempat Penitipan Anak Werdhi Kumara 1, Kodya Denpasar. Sari Pediatri. 10(2)

[5] Artha NM., Sutoma R., Gamayanti, IL. 2014. Kesepakatan Hasil antara Kuesioner PraSkrining Perkembangan, Parent's Evaluation of Developmental Status, dan Tes Denver-IIuntuk Skrining Perkembangan Anak Balita, Sari Pediatri. 16(4), 266-270

[6] Prasida, DW., Maftuchah, Mayangsari D. 2015. Pengaruh Penyuluhan Tentang KPSP terhadap Pengetahuan Guru di Paud Taman Belia Semarang. University Research Coloqium. 570-576

[7] Soedjatmiko. 2001. Deteksi Dini Gangguan Tumbuh Kembang Balita. Sari Pediatri. 3(3), 175188

[8] Dhamayanti M. 2006. Kuesioner Praskrining Perkembangan (KPSP) Anak. Sari Pediatri. 8(1), 9-15

[9] Galit T., Cohen A., Habib S., Tirosh,E. 2011. Decreased Head Circumference Velocity as Related to Developmental Deficit in Infancy. Pediatric Neurology. 47(5), 341-344

[10] Uswatun A., WulandariA. 2011. Hubungan Lingkar Kepala dengan Perkembangan Anak Usia 12-24 Bulan Di Posyandu Tlogowatu Kemalang Klaten. Jurnal Involusi Kebidanan. 1(2), 37

[11] Alfarizi BA., Suarni E. 2015. Hubungan Status Gizi dengan Perkembangan Anak Usia 3-4 Tahun pada 21 Posyandu di Kota Palembang. Syifa' MEDIKA. 6(1), 13

[12] Permenkes. 2014. Pemantauan Pertumbuhan, Perkembangan, dan Gangguan Tumbuh Kembang Anak

[13] Wati DE. 2016. Pengetahuan Guru PAUD Tentang KPSP (Kuisioner Pra Skrining Perkembangan) Sebagai Alat Deteksi Tumbuh Kembang Anak. Varia Pendidikan. 28(2), 133 139

[14] Amouian S., et al. 2017. Assessment of the Relationship between Body Mass Index and Gross Motor Development in Children. Iran J Child Neurol. 11(3), 7-14.

[15] Home Science. 2018. Concept of Development. Available from: https://www.google.co.id/url?sa=t\&source=web\&rct=j\&url=http://nios.ac. 
in/media/documents/SecHmscicous/english/Home\%2520Science (Accesed at : 2018 , December 7)

[16] Spaner RN. 2002. Child Development Guide. Center for Development of Human Services. Research Foundation of SUNY, Bufallo State Collage

[17] Astini DAAAS. 2018. Nutritional Status of Children in Bali-Indonesia. IOP Conf. Series: Materials Science and Engineering 434

[18] Bose K. Concept of Human Physical Growth and Development. Department of Anthropology, Vidyasagar University West Bengal

[19] Dabar D., et al. 2016. A Community-based Study on Growth and Development of Under-Five Children in an Urbanized Village of South Delhi. Journal of Tropical Pediatrics. 62, 446-456 